\title{
Pharmaceutical Particle Engineering via Nano Spray Drying - Process Parameters and Application Examples on the Laboratory- Scale
}

\section{Cordin Arpagaus*}

NTB University of Applied Sciences of Technology Buchs, Institute for Energy Systems, Switzerland

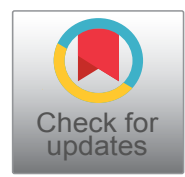

*Corresponding author: Arpagaus Cordin, NTB University of Applied Sciences of Technology Buchs, Institute for Energy Systems, Erdenbergstrasse 4, 9471 Buchs, Switzerland, Tel: +41-81-755-34-94, E-mail: cordin.arpagaus@ntb.ch

\begin{abstract}
Spray drying plays a crucial role in the processing of pharmaceutical products such as pills, capsules, and tablets as it is used to convert drug-containing liquids into dried powdered forms. Nano spray drying is in particular used to improve drug formulation by encapsulating active ingredients in polymeric wall materials for protection and delivering the drugs to the right place and time in the body. The nano spray dryer developed in the recent years extends the spectrum of produced powder particles to the submicron- and nanoscale with very narrow size distributions and sample quantities in the milligram scale at high product yields. This enables the economical use of expensive active pharmaceutical ingredients and pure drugs. The present paper explains the concept of nano spray drying in the laboratory-scale and discusses the influence of the main process parameters on the final powder properties like particle size, morphology, encapsulation efficiency, and drug loading. Application results of nano spray drying for the formulation and encapsulation of different drugs are reviewed.
\end{abstract}

\section{Keywords}

Nano spray drying, Pharmaceuticals, Drug encapsulation, Particle size, Powder

\section{Introduction}

Spray drying is a simple, fast, continuous, and scalable drying technology that is well established in the pharmaceutical industry for excipient production, microencapsulation, or granulation [1]. Many pharmaceutical products such as pills, capsules, and tablets are processed in dried powdered form. Progress was made in introducing spray-drying technology to the pharma- ceutical industry. Table 1 lists some examples of marketed pharmaceutical products processed by spray drying technology [2-8].

Typically, the drug is dissolved in a polymeric carrier solution and atomized into hot gas to evaporate the solvent, resulting in particles containing the drug dispersed in an amorphous polymer matrix [9]. Polymers such as hydroxypropyl methylcellulose or its acetate succinate have become the first choice for the preparation of stable solid dispersions as they are resistant to water absorption [3]. A few spraydried pharmaceutical products are on the market for inhalation therapies. In 2013, the US Food and Drug Administration approved Novartis TOBI $^{\circledR}$ Podhaler $^{\mathrm{T}}$ with $28 \mathrm{mg}$ Tobramycin inhalation powder per capsule for the treatment of cystic fibrosis patients with Pseudomonas aeruginosa bacteria in the lungs. The Tobramycin inhalation powder is manufactured using PulmoSphere ${ }^{\mathrm{TM}}$ technology, an emulsion-based spray drying process that produces spherical hollow-porous particles (Figure 1).

The dried particles have a geometric mean diameter of about 1 to $2.7 \mu \mathrm{m}$ and a mean mass diameter of $<4 \mu \mathrm{m}$, which is ideal for delivering the drug to the lower respiratory [5,6]. Spray dried powder consists of $28 \mathrm{mg}$ Tobramycin active ingredient with distearoylphosphatidylcholine calcium chloride and sulfuric acid for $\mathrm{pH}$ adjustment. The drug is packaged in a hypromellose capsule containing $28 \mathrm{mg}$ of active ingredient each. The capsules are stored individually

Citation: Arpagaus C (2018) Pharmaceutical Particle Engineering via Nano Spray Drying - Process Parameters and Application Examples on the Laboratory-Scale. Int J Med Nano Res 5:026. doi. org/10.23937/2378-3664/1410026

Accepted: December 03, 2018: Published: December 05, 2018

Copyright: (C) 2018 Arpagaus C. This is an open-access article distributed under the terms of the Creative Commons Attribution License, which permits unrestricted use, distribution, and reproduction in any medium, provided the original author and source are credited. 
Table 1: Examples of FDA-approved medicaments that use spray drying technology as preparation method. HPMC: Hydroxypropyl Methylcellulose; HPMCAS: Hydroxypropyl Methylcellulose Acetate Succinate; DSPC: Distear-ylphosphatidylcholine (data summarized from [2-8]).

\begin{tabular}{|c|c|c|c|c|c|c|}
\hline Trade name & Drug & Application & Polymer, Excipient & Maximum drug dose & Company & $\begin{array}{c}\text { FDA } \\
\text { approval }\end{array}$ \\
\hline Prograf & Tacrolimus & $\begin{array}{c}\text { Immunosuppressant } \\
\text { (prevents organ } \\
\text { rejection) }\end{array}$ & HPMC & 5 mg per capsule & $\begin{array}{l}\text { Astellas } \\
\text { Pharma }\end{array}$ & 1994 \\
\hline Exhubera & Insulin & Diabetes & $\begin{array}{l}\text { Mannitol, glycine, } \\
\text { sodium citrate }\end{array}$ & 1 or 3 mg per capsule & $\begin{array}{l}\text { Pfizer/ } \\
\text { Nektar }\end{array}$ & 2006 \\
\hline Intelence & Etravirine & HIV medicine & HPMC & $\begin{array}{c}100 \text { or } 200 \text { mg per } \\
\text { tablet }\end{array}$ & Janssen & 2008 \\
\hline Zortress & Everolimus & $\begin{array}{c}\text { Immunosuppressant } \\
\text { (prevents organ } \\
\text { rejection) }\end{array}$ & HPMC & $0.75 \mathrm{mg}$ per tablet & Novartis & 2010 \\
\hline $\begin{array}{c}\text { Aridol/Osmohale, } \\
\text { Bronchitol }\end{array}$ & - & Asthma/ Cystic fibrosis & Mannitol & 5 to $40 \mathrm{mg}$ per capsule & Pharmaxis & 2010 \\
\hline Incivek & Telaprevir & Hepatitis C & HPMCAS & $375 \mathrm{mg}$ per tablet & Vertex & 2011 \\
\hline Kalydeco & Ivacaftor & Cystic fibrosis & HPMCAS & $150 \mathrm{mg}$ per tablet & Vertex & 2012 \\
\hline TOBI Podhaler & Tobramycin & Inhalation therapy & $\begin{array}{l}\text { DSPC, calcium } \\
\text { chloride, sulfuric } \\
\text { acid }\end{array}$ & $28 \mathrm{mg}$ per capsule & Novartis & 2013 \\
\hline Raplixa & - & $\begin{array}{l}\text { Bleeding control during } \\
\text { surgery }\end{array}$ & $\begin{array}{l}\text { Fibrinogen/ } \\
\text { Thrombin }\end{array}$ & $\begin{array}{c}79 \mathrm{mg} / 726 \mathrm{IU} \text { per gram } \\
\text { powder }\end{array}$ & $\begin{array}{c}\text { Nova } \\
\text { Laboratories }\end{array}$ & 2016 \\
\hline
\end{tabular}
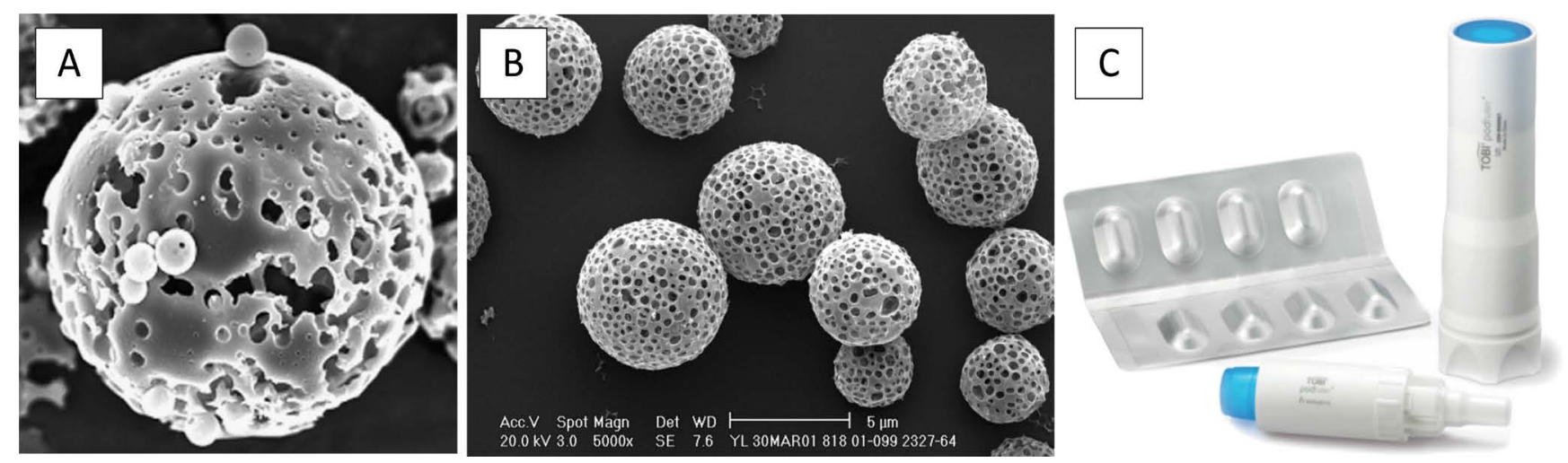

Figure 1: Tobramycin inhalation powder. (A) Scanning electron microscope pictures of hollow and porous PulmoSphere ${ }^{\mathrm{TM}}$ particles [5,6], (C) Novartis TOBI ${ }^{\circledR}$ Podhaler ${ }^{\mathrm{TM}}$ for dry powder inhalation depicted with day's supply of Tobramycin inhalation powder with 2 separate blister packs of $4 \times 28 \mathrm{mg}$ capsules [5].

in aluminum blister packs of four to protect them from moisture in the environment. Pharmaxis commercialized spray dried inhalable mannitol (sugar alcohol) powders Aridol/Osmohale ${ }^{\mathrm{TM}}$ and Bronchito ${ }^{\mathrm{TM}}$ in 2011 and 2012 for diagnosis of asthma by detecting active airway inflammation through measuring bronchial hyperresponsiveness [7]. Mannitol is crystalline after spray drying and physically stable due to its low glass transition temperature. It rehydrates the airway/lung surface and promotes a productive cough. Bronchitol dry powder helps to increase mucus clearance and improves the lung function and the quality of life of people living with cystic fibrosis.

Already in 2006, Exubera ${ }^{\circledR}$ (Pfizer/Nektar Therapeutics) became the first inhaled human insulin approved for use in type 1 or type 2 diabetes [8]. Exubera powder was prepared by spray drying $60 \%$ recombinant human insulin mixed with glycine, mannitol, and sodium citrate as stabilizers. The spray dried powders exhibited good flowability, low moisture content, and good storage stability at room temperature. The aerosolized insulin had a mass median aerodynamic diameter of approximately $3 \mu \mathrm{m}$. The spray-dried insulin powder was packaged in blisters containing $1 \mathrm{mg}$ or $3 \mathrm{mg}$ of insulin. Despite the promise of a new delivery system, Exubera was not profitable in the insulin market and the product was withdrawn in 2007 because of low sales. New strategies for the administration of inhaled insulin are being further investigated.

In May 2015, the FDA approved Raplixa, the first sterile, spray dried fibrin seal powder used to control adult bleeding during surgery [8]. The powder is applied to the sampling site directly from the vial or by using a low-pressure spray device. The fibrin sealant then dissolves in the blood and begins to clot the blood. Raplixa comprises spray-dried thrombin and spraydried fibrinogen, which are aseptically mixed and filled into a single vial. Each gram of Raplixa contains $79 \mathrm{mg}$ fibrinogen and $726 \mathrm{IU}$ thrombin. This eliminates the need to combine fibrinogen and thrombin before use 
and the product can be stored at room temperature. Commercial supplies of Raplixa sealing powder are produced at the sterile production facilities of Nova Laboratories by aseptic spray drying.

From a technological point of view spray drying offers flexibility in particle formulation. By tuning the spray drying parameters, it is possible to manipulate the particle properties, e.g. particle size, shape, morphology, surface roughness, or surface composition.

In the course of the rapid progress of nanoencapsulation techniques, nano spray drying technology has also developed, in particular at Buchi Labortechnik AG (Switzerland), with the development of the Nano Spray Dryer B-90 [10-14]. The laboratory-scale nano spray dryer enables the formulation of drugs with solid colloidal particles in the submicron range. Detailed information on the formation of nanocapsules by the nano spray drying technology can be found in several review studies [1024], in particular in a recently published book chapter and review paper by Arpagaus et al. [17,19]. The term nanoparticle in the pharmaceutical industry is typically defined as solid colloidal particles with sizes below $1 \mu \mathrm{m}$
$[10,14,23,25,26]$. Nano spray drying enables the encapsulation of active ingredients in polymeric wall materials providing enhanced environmental protection (e.g. against oxidation, light, and temperature), stability, handling, storage, and controlled drug release properties. The nanonization and structural change improves the particle solubility and redispersibility of the final drug product in aqueous solutions.

This study explains the concept of nano spray drying, the influence of the main process parameters on the powder properties (e.g. particle size, morphology, encapsulation efficiency, drug loading), and discusses different pharmaceutical applications realized in the laboratory-scale.

\section{Process Parameters of a Nano Spray Dryer}

Figure 2 shows a schematic representation and the functional principle of a nano spray dryer. The adjustable process parameters (e.g. drying gas flow rate, inlet temperature, and spray rate) and formulation variables (e.g. feed composition, solid concentration) are colored in black. The resulting parameters like the

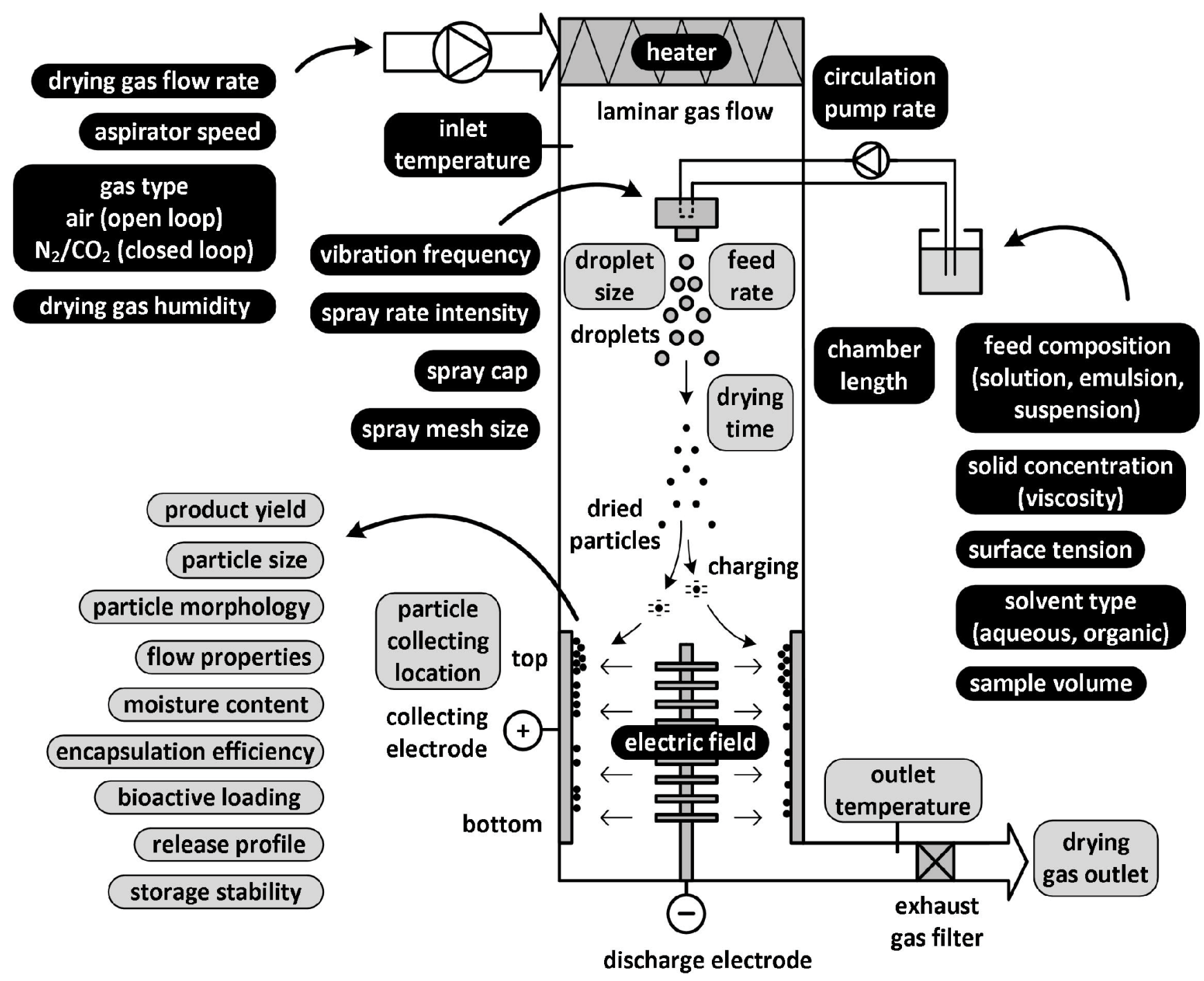

Figure 2: Elements of a nano spray dryer at laboratory-scale. Black: Adjustable process parameters and formulation variables. Grey: Resulting output parameters (adapted from [17,19,28]). 

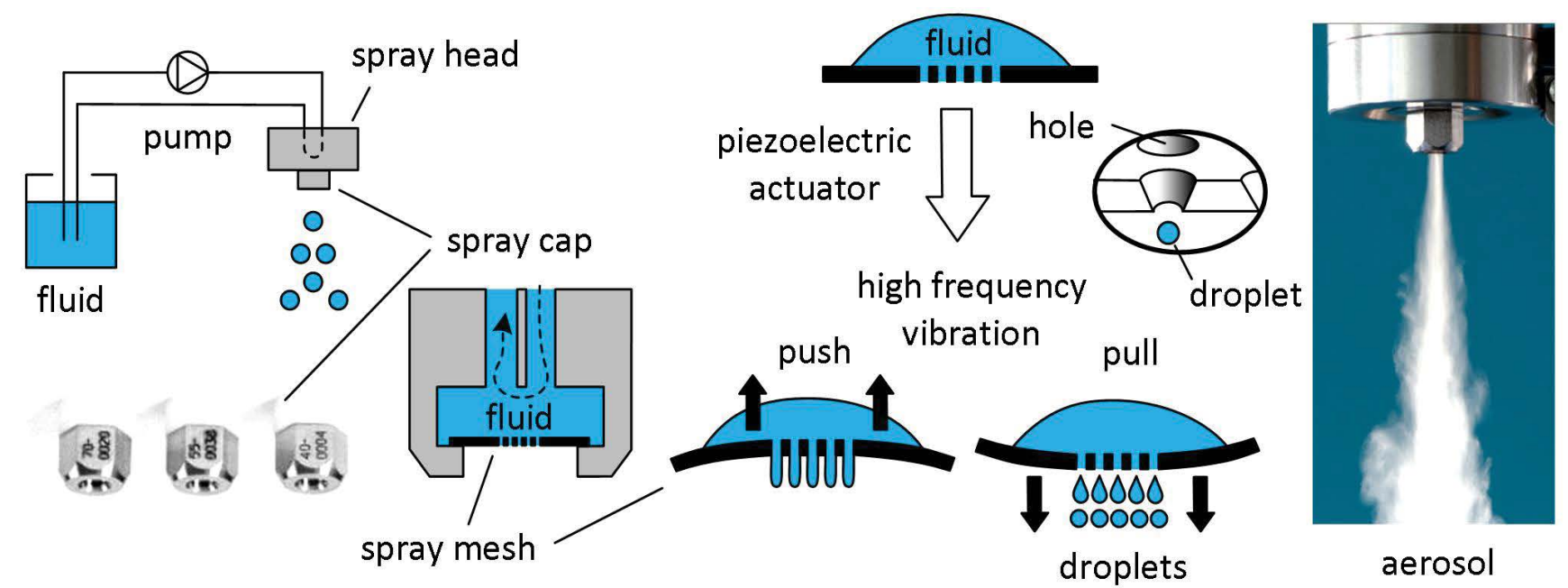

Figure 3: Vibrating mesh technology to produce an ultrafine spray in a nano spray dryer (adapted from [19]).
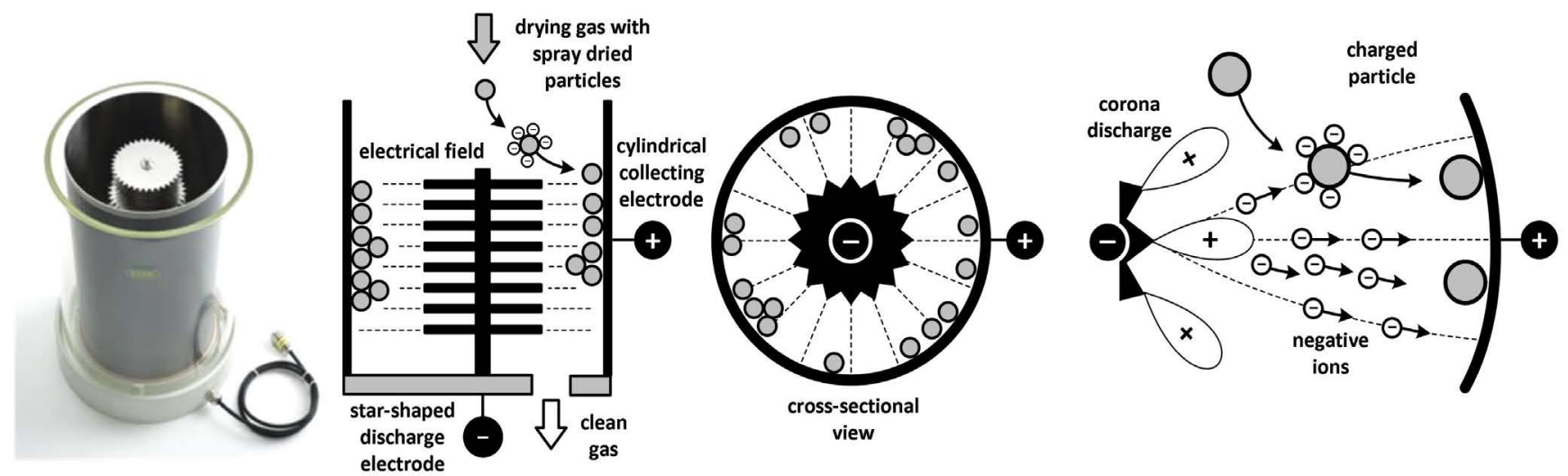

Figure 4: Principle of an electrostatic powder collector implemented in the nano spray dryer to extend the size spectrum of separable particles to the nanoscale (adapted from [19]).

drying gas outlet temperature, the droplet and dried particle size, the product yield, and others are marked in grey. Overall, nano spray drying offers flexibility for formulation and a whole range of process parameters influence the final spray dried particle properties.

The droplet generation is based on vibrating mesh technology, which has been adapted from nebulizers used in aerosol drug delivery (Figure 3). A piezoelectric actuator vibrates a small replaceable spray cap at ultrasonic frequency. The cap comprises a thin perforated metal mesh containing a series of tiny laser drilled holes. Figure 3 illustrates a typical hole in the mesh. The piezoelectric vibration leads to a fast upward and downward movement of the spray mesh, thus ejecting millions of precisely sized droplets through the holes into the drying chamber. The droplet size depends on the mesh size and the physicochemical properties of the fluid, such as viscosity and surface tension. Spray meshes are available with 4.0, 5.5, and $7.0 \mu \mathrm{m}$ hole diameters [19]. With a $4.0 \mu \mathrm{m}$ spray mesh approximately 3 to $8 \mu \mathrm{m}$ water droplets are produced $[12,19,27]$.

The co-current drying gas flow is heated up to the set inlet temperature and directs the particles to the electrostatic particle collector. The dried particles are electrostatically charged and captured at high efficiency $[14,20]$. The flow of the drying gas is laminar, which makes the system suitable for gentle drying heatsensitive products with a low risk of degradation or loss of activity. The drying gas exits the spray dryer in a purified form and the outlet temperature is measured.

The electrostatic particle collector can capture submicron particles $(<1 \mu \mathrm{m})$ at a separation efficiency greater than $99 \%$ for small solid batches of 30 to $500 \mathrm{mg}$ $[10,12,14,15]$ (Figure 4). The electrostatic precipitator can even collect thin-walled particles without breaking $[29,30]$. The particles are gently removed from the internal surface of the collecting electrode cylinder by utilizing the particle scraper and particle collecting paper that are included in the delivery of the laboratory instrument. Uniquely high yields of 76 to $96 \%$ are obtained, thus enabling the economical use of expensive pharmaceutical ingredients and pure drugs.

During spray drying, the cooling effect of the evaporating solvent keeps the droplet temperature low, so that heat sensitive products like proteins, peptides, hormones, or amino acids can be stabilized 
Table 2: Influence of the main process parameters in nano spray drying ( $/ \downarrow$ strong, $\uparrow / \downarrow$ weak increasing/decreasing influence, - minimal or no influence) (adapted from [19]).

\begin{tabular}{|c|c|c|c|c|c|c|c|}
\hline Process parameter & $\begin{array}{c}\text { Outlet } \\
\text { temperature }\end{array}$ & $\begin{array}{c}\text { Droplet } \\
\text { size }\end{array}$ & $\begin{array}{c}\text { Particle } \\
\text { size }\end{array}$ & $\begin{array}{l}\text { Feed } \\
\text { rate }\end{array}$ & $\begin{array}{c}\text { Moisture } \\
\text { content }\end{array}$ & Yield & Stability \\
\hline Drying gas flow rate $\uparrow$ & 1 & - & - & - & 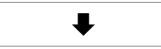 & - & - \\
\hline Drying gas humidity $\uparrow$ & $\uparrow$ & - & - & - & 个 & $\downarrow$ & - \\
\hline Inlet temperature $\uparrow$ & 个 & - & $\uparrow$ & - & $\downarrow$ & $\uparrow$ & $\sqrt{t}$ \\
\hline Spray mesh size $\uparrow$ & $\downarrow$ & $\boldsymbol{1}$ & $\boldsymbol{1}$ & $\boldsymbol{1}$ & - & - & $\uparrow$ \\
\hline Spray rate intensity $\uparrow$ & $\sqrt{t}$ & $\uparrow$ & $\uparrow$ & $\boldsymbol{1}$ & $\uparrow$ & - & $\sqrt{t}$ \\
\hline Circulation pump rate $\uparrow$ & - & $\uparrow$ & $\uparrow$ & $\uparrow$ & - & - & $\uparrow$ \\
\hline Solid concentration $\uparrow$ & $\uparrow$ & - & -1 & t & $\downarrow$ & $\uparrow$ & - \\
\hline Surfactant/stabilizer $\uparrow$ & - & $\downarrow$ & $\downarrow$ & $\uparrow$ & - & - & - \\
\hline Solvent instead of water & 1 & $\downarrow$ & $\downarrow$ & $\uparrow$ & 7 & $\uparrow$ & - \\
\hline
\end{tabular}
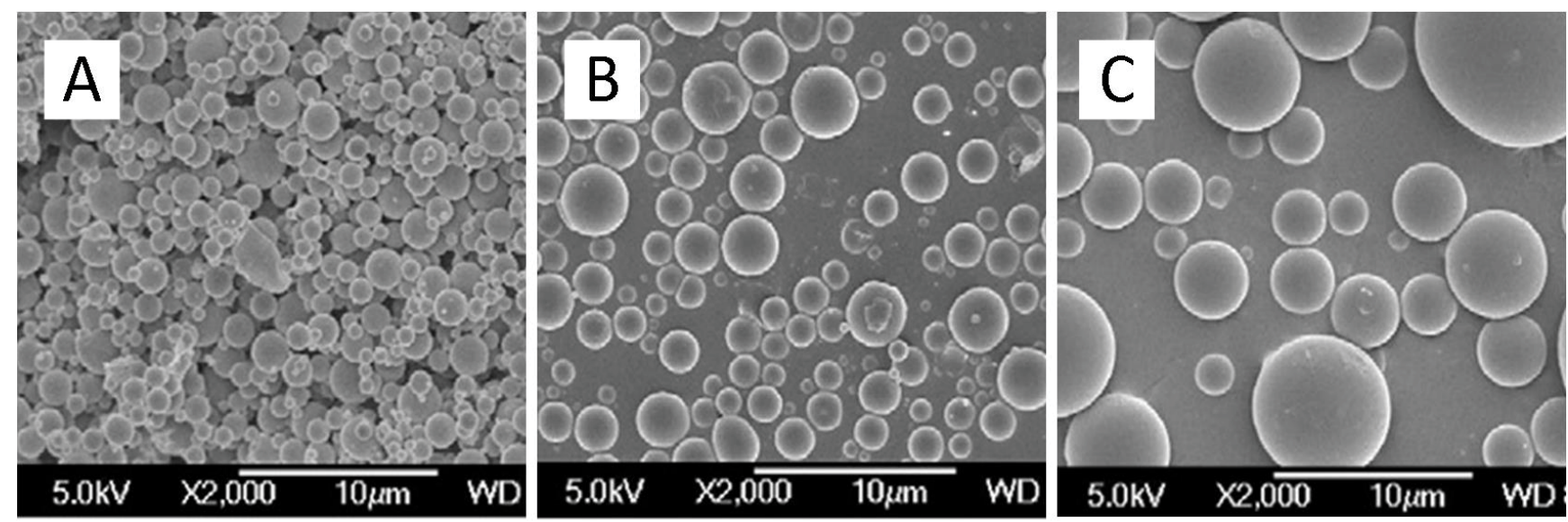

Figure 5: Nano spray dried bovine serum albumin particles using a (A) $4.0 \mu \mathrm{m}$, (B) $5.5 \mu \mathrm{m}$, and (C) $7.0 \mu \mathrm{m}$ spray mesh. Particles of approximately $0.7,1.7$, and $2.6 \mu \mathrm{m}$ mean size were achieved at $1 \%(\mathrm{w} / \mathrm{v})$ solid concentration (pictures from [14] with permission from Elsevier).
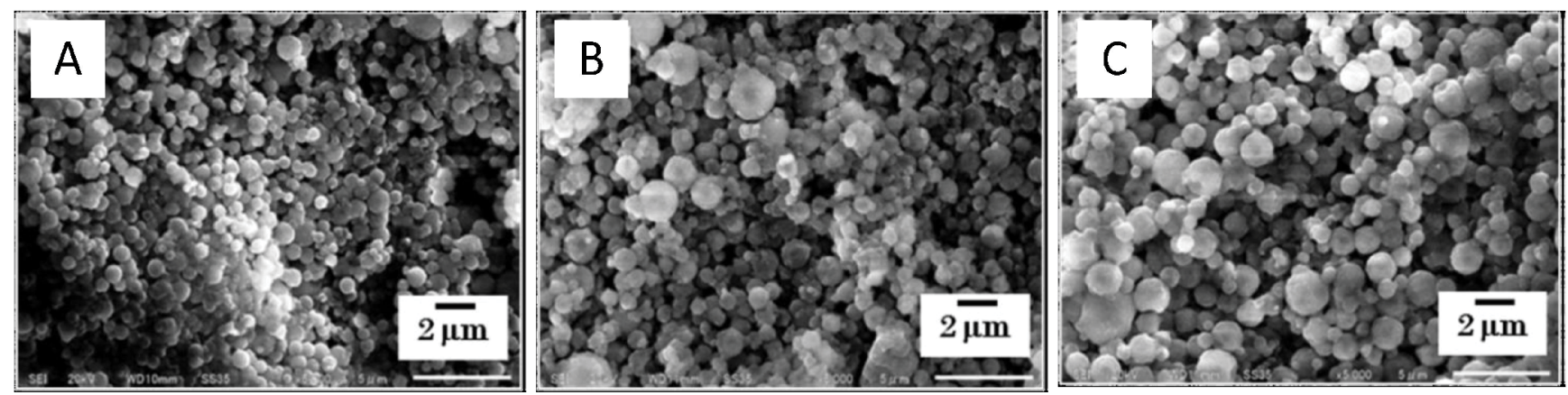

Figure 6: Nano spray dried fluorometholone nanocrystals prepared using spray mesh sizes of (A) $4.0 \mu \mathrm{m},(\mathrm{B}) 5.5 \mu \mathrm{m}$, and (C) $7.0 \mu \mathrm{m}$. The particles were $620 \pm 268,795 \pm 285$, and $856 \pm 344 \mathrm{~nm}$ in size (open access pictures from [33]).

in nanopowder forms at optimized product yields and dried with negligible degradation.

Table 2 gives an overview of the main process parameters and their influence on the output parameters (i.e. outlet temperature, droplet size, feed rate) and the final product properties (i.e. particle size, moisture content, yield, stability). The thickness of each arrow illustrates the strength of the related influence. The key parameters controlling the final particle size are the spray mesh size and the solid concentration. The submicron size is typically reached when a $4.0 \mu \mathrm{m}$ spray mesh and diluted solutions of 0.1 to $1 \%(\mathrm{w} / \mathrm{v})$ are used.
Several authors investigated the investigated the relationship between spray mesh aperture size and particle size of drugs. The spray mesh size determines directly the size of the droplets and consequently the dried solid particles. As examples, Figure 5 and Figure 6 shows some SEM images of the model protein bovine serum albumin and the asthma drug fluorometholone obtained with a 4.0, 5.5, and $7.0 \mu \mathrm{m}$ spray mesh respectively. The average particle size decreased with decreasing mesh aperture size producing smaller droplet, for the fluorometholone particles $620 \pm 268$, $795 \pm 285$, and $856 \pm 344 \mathrm{~nm}$ for mesh aperture sizes of $4.0,5.5$, and $7.0 \mu \mathrm{m}$, respectively. The bovine serum 
Table 6: Typical first-guess experimental process parameters for nano spray drying of pharmaceuticals.

\begin{tabular}{|c|c|c|c|c|c|c|c|}
\hline Solvent & $\begin{array}{c}\text { Inlet drying } \\
\text { temperature } \\
{\left[{ }^{\circ} \mathrm{C}\right]}\end{array}$ & $\begin{array}{c}\text { Outlet drying } \\
\text { temperature } \\
{\left[{ }^{\circ} \mathrm{C}\right]}\end{array}$ & $\begin{array}{c}\text { Drying gas } \\
\text { type }\end{array}$ & $\begin{array}{c}\text { Drying gas } \\
\text { flow rate [L/ } \\
\text { min] }\end{array}$ & $\begin{array}{c}\text { Solid } \\
\text { concentration } \\
{[\% \mathrm{w} / \mathrm{v}]}\end{array}$ & $\begin{array}{c}\text { Spray } \\
\text { mesh size } \\
{[\mu \mathrm{m}]}\end{array}$ & $\begin{array}{c}\text { Feed } \\
\text { Rate } \\
\text { [mL/h] }\end{array}$ \\
\hline $\begin{array}{c}\text { Water } \\
\text { Ethanol } \\
\text { Acetone } \\
\text { DCM }\end{array}$ & $\begin{array}{l}60 \text { to } 120 \\
50 \text { to } 110 \\
40 \text { to } 70 \\
30 \text { to } 50\end{array}$ & $\begin{array}{l}30 \text { to } 60 \\
30 \text { to } 50 \\
25 \text { to } 40 \\
20 \text { to } 35\end{array}$ & $\begin{array}{c}\text { Air } \\
\text { Air } \\
\text { Inert gas }\left(\mathrm{N}_{2} / \mathrm{CO}_{2}\right)\end{array}$ & $\begin{array}{l}100 \text { to } 140 \\
100 \text { to } 120 \\
90 \text { to } 120 \\
80 \text { to } 120\end{array}$ & 0.1 to 10 & $\begin{array}{l}4.0 \\
5.5 \\
7.0\end{array}$ & $\begin{array}{c}5 \text { to } 25 \\
20 \text { to } 65 \\
30 \text { to } 160\end{array}$ \\
\hline
\end{tabular}

albumin particles were approximately $0.7,1.7$, and 2.6 $\mu \mathrm{m}$ in size respectively at $1 \%(\mathrm{w} / \mathrm{v})$ solid concentration.

The validity of these results is supported by various reports $[14,17,19,31]$. It should be noted here that at an ultrasonic vibration frequency of $100 \mathrm{kHz}$ and assuming 100 active holes per spray mesh, a fine mist of around 10 million droplets per second is produced.

Table 3 presents the particle sizes that have been realized by nano spray drying for various pharmaceutical applications. The key parameters controlling the final particle size are the spray mesh size $[14,31,32]$ and the solid concentration $[10-12,14,27]$. Smaller droplets are favored by a higher viscosity, a lower surface tension, and a smaller spray mesh [14,15,33-35]. The region of submicron particle size is typically reached when using a $4.0 \mu \mathrm{m}$ spray mesh and diluted solutions of 0.1 to $1 \%$ $(\mathrm{w} / \mathrm{v})$. Further reduction of particle size is possible by further dilution, as demonstrated in several studies [10,14,31,33,36-39].

Depending on the application, an optimized set of process parameters can be found, e.g. by design of experiment studies, as shown by several authors $[10,15,16,19]$. The selection of the organic solvent is based on the drug solubility and the encapsulating wall materials, as well as on the required drying temperatures. For aqueous applications, the outlet temperatures range between 28 and $59{ }^{\circ} \mathrm{C}$ [20]. The optimal drying temperatures of for example poly(lacticco-glycolic acid) (PLGA) dissolved in dichloromethane lies in a range of 29 to $32{ }^{\circ} \mathrm{C}$ [16].

Typical organic solvents applied in nano spray drying of pharmaceuticals are:

- dichloromethane (DCM) [16,33,40-44],

- acetone [10,44-50],

- ethanol $[15,31,32,51,52]$,

- methanol [27,53-56],

- acetonitrile [57,58],

- ethyl acetate [44], and

- mixtures thereof with water [59-65].

The selection of the organic solvent is based on the solubility of the drug and the encapsulating wall materials (e.g. excipients). The mixing ratio is adjusted to allow the complete dissolution of the compounds [61].
For example, acetone-water mixtures dissolve steroidal dexamethasone well, and the low viscosity of the acetone allows higher flow rates through the vibrating spray mesh, which shortens the processing time [48]. Compared to water, organic solvents generate slightly smaller droplets due to their lower surface tension, viscosity, and density [54]. In addition, organic solvents enable lower drying temperatures because of the lower boiling points. Dichloromethane $\left(40{ }^{\circ} \mathrm{C}\right)$ or acetone $\left(56{ }^{\circ} \mathrm{C}\right.$ ) lead to fast drying and prevent particles from sticking to the walls or agglomerating. The evaporation temperature is lower than the melting temperature or the glass transition temperature of certain polymers (Table 3).

Numerous excipients, dispersing agents, binders and stabilizers are applied in drug formulation studies, including:

- water-soluble saccharides (e.g. Arabic gum, alginate, chitosan, cyclodextrin, cellulose derivatives, modified starch, maltodextrin, pectin, mannitol, lactose trehalose),

- proteins (i.e. gelatin, serum albumin, whey protein, sodium caseinate, silk fibroin, leucine),

- water-soluble synthetic polymers (e.g. poly(vinyl alcohol), poly(ethylene glycol) or poly(acrylic acid) (Carbopol)),

- hydrophobic synthetic polymers (e.g. PLGA, poly ( $\varepsilon$-caprolactone), poly(vinyl pyrrolidone) (Kollidon), Eudragit), and

- fats (e.g. stearic acid and glyceryl behenate (Compritol)).

The selection of a suitable matrix excipient is essential for the encapsulation of drugs by nano spray drying to achieve the desired decomposition of the particles and the drug release in the lungs.

- Mannitol, chitosan, leucine, lactose, and trehalose are widely used due to their high aqueous solubility and low toxicity.

- The hygroscopic excipient mannitol is especially advantageous for the treatment of bacterial infections in cystic fibrosis $[70,71]$.

- Chitosan offers several advantages for mucosal delivery, such as low toxicity and good biodegradability as well as antibacterial activity [36,62,68,72-74]. 
Table 3: Influence of spray mesh size on final nano spray dried particle size in nm (n.a. = data not available).

\begin{tabular}{|c|c|c|c|c|c|c|}
\hline \multirow{2}{*}{ Substance } & \multirow{2}{*}{ Solvent } & \multirow{2}{*}{$\begin{array}{l}\text { Concentration } \\
(\% \mathrm{w} / \mathrm{v})\end{array}$} & \multicolumn{3}{|c|}{ Mesh size } & \multirow{2}{*}{ Reference } \\
\hline & & & $4.0 \mu \mathrm{m}$ & $5.5 \mu \mathrm{m}$ & $7.0 \mu \mathrm{m}$ & \\
\hline Chitosan (low-density) & $0.5 \%$ acetic acid & 0.025 & 95 & 215 & 265 & [36] \\
\hline Ethambutol & Water & 1 & 220 & n.a. & n.a. & [66] \\
\hline \multirow{3}{*}{$\begin{array}{l}\text { Gentamicin sulfate } \\
\text { in alginate/pectin }\end{array}$} & \multirow{3}{*}{ Water } & 0.1 & 310 & 520 & 850 & \multirow{3}{*}{ [34] } \\
\hline & & 0.25 & 345 & 550 & 980 & \\
\hline & & 0.5 & 405 & 610 & 1,000 & \\
\hline \multirow{2}{*}{ Arabic gum } & \multirow{2}{*}{ Water } & 0.1 & 355 & \multirow{2}{*}{ n.a. } & \multirow{2}{*}{ n.a. } & \multirow{2}{*}{ [10] } \\
\hline & & 1 & 580 & & & \\
\hline \multirow{2}{*}{ Whey protein } & \multirow{2}{*}{ Water } & 0.1 & 420 & \multirow{2}{*}{ n.a. } & \multirow{2}{*}{ n.a. } & \multirow{2}{*}{ [10] } \\
\hline & & 1 & 595 & & & \\
\hline \multirow{2}{*}{ Sodium chloride } & \multirow{2}{*}{ Water } & 0.1 & 515 & \multirow{2}{*}{ n.a. } & \multirow{2}{*}{ n.a. } & \multirow{2}{*}{ [10] } \\
\hline & & 1 & 995 & & & \\
\hline Disodium phosphate & Water & 0.1 & 500 & n.a. & n.a. & [12] \\
\hline Trehalose & Water & 0.1 & 800 & n.a. & n.a. & [12] \\
\hline Bovine serum albumin & \multirow{2}{*}{ Water } & 0.1 & 460 & n.a. & n.a. & \multirow{2}{*}{ [14] } \\
\hline (with surfactant) & & 1 & 700 & 1,700 & 2,600 & \\
\hline Sodium alginate & Water & 0.13 & 760 & n.a. & n.a. & [67] \\
\hline Vancomycin in chitosan & $0.5 \%$ acetic acid & 0.2 & 450 & n.a. & n.a. & [68] \\
\hline Curcumin in albumin & Water & 0.5 & 715 & n.a. & n.a. & [69] \\
\hline Salbutamol sulfate & Water & 1 & 1,000 & 1,600 & 3,100 & [35] \\
\hline Galactosidase in trehalose & Water & 5 & 1,800 & 4,500 & 4,900 & [15] \\
\hline \multirow[b]{2}{*}{$\mathrm{CsH}_{2} \mathrm{PO}_{4}$} & Methanol:water & 0.1 & 200 & 300 & 500 & \multirow{2}{*}{ [54] } \\
\hline & $(56: 44)$ & 1 & 540 & n.a. & n.a. & \\
\hline Calpain inhibitor & \multirow{2}{*}{ Ethanol } & 0.05 & 420 & 605 & 845 & \multirow{2}{*}{ [32] } \\
\hline steroid nanocrystals & & 0.5 & 995 & n.a. & n.a. & \\
\hline Fluorometholone & Ethanol & 0.1 & 620 & 795 & 855 & [31] \\
\hline Dexamethasone & Ethanol & 1 & 835 & 1,100 & 1,300 & [31] \\
\hline PLGA & DCM & 1 & n.a. & 3,200 & 4,200 & [43] \\
\hline Ethyl cellulose & DCM & 1 & 1,500 & 2,700 & 3,400 & [42] \\
\hline & & 0.5 & n.a. & 570 & n.a. & \\
\hline & & 1 & n.a. & 760 & n.a. & קי \\
\hline PLGA & DCM & 2 & 685 & 830 & 930 & [33] \\
\hline & & 5 & n.a. & 1,100 & n.a. & \\
\hline
\end{tabular}

- Leucine is a very popular dispersion enhancer to increase the flowability of nano spray dried particles, as shown in various pulmonary drug delivery studies [30,59-62,64,73,75-82].

Table 4 summarizes typical process parameters of various wall materials (excipients) used as dispersants, binders and stabilizers in the nano spray drying of pharmaceuticals at laboratory-scale.

The morphology of particles prepared by nano spray drying depends on the drying conditions and the feed properties. Dense, hollow, porous, composites, and encapsulated structures (i.e. single-core, multicore, irregular, or multi-walled) with spherical, wrinkled, shriveled, or even doughnut-like shapes can be obtained [19]. Figure 7 illustrates some examples of nano spray dried particles including salbutamol, albuterol in mannitol, cyclosporine in PLGA, trehalose, $\beta$-galactosidase in trehalose, and bovine serum albumin.

In general, slow drying leads to more compact particles, while fast and high temperature drying favors the formation of hollow particles with thin shells. Surfactants balance the surface-to-viscous forces inside of the drying droplet and enable the formation of a smooth spherical surface. Composite particles prepared from suspensions and nano spray drying provide a high specific surface area. Most nano spray dried drugs tend to be amorphous due to the too short drying time to form crystalline structures. To prevent recrystallization, the dried powders are stored under dry and controlled conditions.

of primary interest for pharmaceuticals are the effects on the particle size, morphology, yield, productivity, encapsulation efficiency, drug loading, drug release profile, and stability.

Table 5 summarizes some representative literature data on encapsulation efficiency and drug exposure. Particles with an encapsulation efficiency of over $95 \%$ and an adjustable drug load were produced. Further information on yield and optimized process parameters of nano spray drying are given.

Applications of Nano Spray Dried Pharmaceuticals on the Laboratory-Scale

The number of publications on nano spray dried 

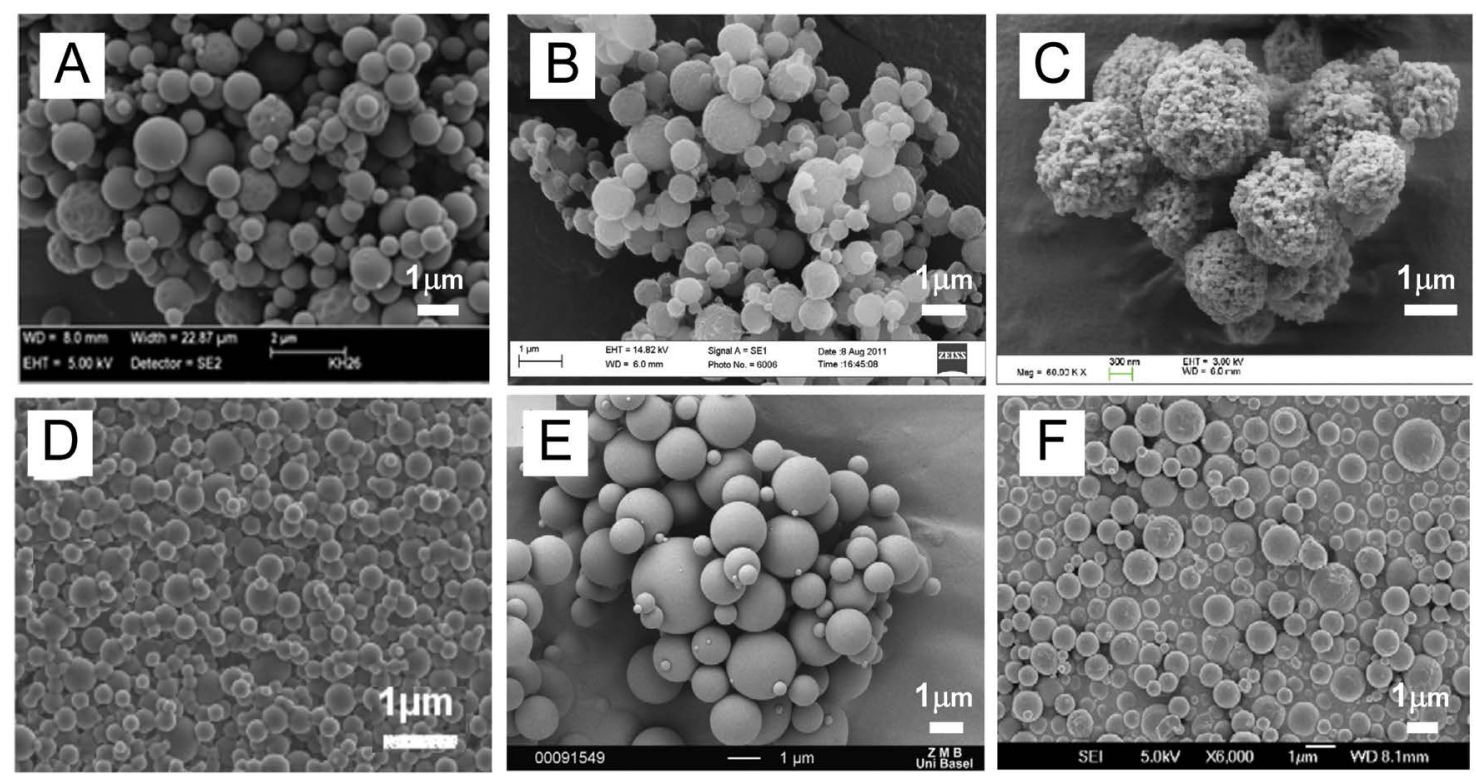

Figure 7: Examples of nano spray dried particles: A: Salbutamol sulfate ( $1 \%$ solid concentration, nano spray dried at $100{ }^{\circ} \mathrm{C}$ ) [37]; B: Albuterol sulfate in mannitol, L-leucine and poloxamer 188 (30:48:20:2 mixing ratio, 0.5\% in water-ethanol solution (80:20), $70^{\circ} \mathrm{C}$ ) [65]; C: Cyclosporin in PLGA (50:50, $15 \mathrm{kDa}$, dissolved in DCM, $29^{\circ} \mathrm{C}$ ) [16]; D: Trehalose with addition of $0.005 \%$ polysorbate $20\left(0.1 \%, 120^{\circ} \mathrm{C}\right)$ [12]; $\mathrm{E}$ : $\beta$-galactosidase in trehalose $\left(1: 2\right.$ mixing ratio, $\left.5 \%, 80^{\circ} \mathrm{C}\right)[15]$; $\mathrm{F}$ : Bovine serum albumin with $0.05 \%$ Tween $80\left(0.5 \%, 120^{\circ} \mathrm{C}\right)[14]$.

Table 4: Different wall materials applied for encapsulation of pharmaceuticals by nano spray drying ( $\mathrm{n} . \mathrm{a}$. = not available).

\begin{tabular}{|c|c|c|c|c|c|c|c|c|}
\hline $\begin{array}{l}\text { Encapsulation wall } \\
\text { materials (excipient) }\end{array}$ & Solvent & $\mathrm{T}$ in $\left({ }^{\circ} \mathrm{C}\right)$ & $\begin{array}{l}\text { T out } \\
\left({ }^{\circ} \mathrm{C}\right)\end{array}$ & $\begin{array}{l}\text { Drying } \\
\text { gas (L/ } \\
\text { min) }\end{array}$ & $\begin{array}{l}\text { Particle } \\
\text { size }(\mu \mathrm{m})\end{array}$ & $\begin{array}{l}\text { Solid } \\
\text { sample } \\
\text { amount } \\
(\mathrm{mg})\end{array}$ & $\begin{array}{l}\text { Product } \\
\text { yield }(\%)\end{array}$ & References \\
\hline $\begin{array}{l}\text { Arabic gum, whey protein, } \\
\text { maltodextrin, polyvinyl } \\
\text { alcohol and modified starch }\end{array}$ & Water & 100 & 38 to 60 & 100 & 0.2 to 1.1 & 30 to 300 & 43 to 95 & [10] \\
\hline $\begin{array}{l}\text { Sodium alginate } \\
\text { (polysaccharide) }\end{array}$ & Water & 110 & n.a. & 100 & 0.4 to 1.2 & n.a. & $>90$ & {$[67]$} \\
\hline $\begin{array}{l}\text { Trehalose, mannitol or } \\
\text { disodium phosphate } \\
\text { surfactant, polysorbate }\end{array}$ & Water & 60 to 100 & 30 to 45 & 115 & 0.3 to 3 & 10 to 50 & 50 to 78 & {$[11,12,27]$} \\
\hline $\begin{array}{l}\text { Leucine (amino acid, } \\
\text { dispersing agent), } \\
\text { Trehalose (stabilizer, } \\
\text { increases shelf life) }\end{array}$ & Water & 75 & 45 & 100 & 2.1 to 5.4 & n.a. & n.a. & [29] \\
\hline $\begin{array}{c}\text { Nanosuspension of mannitol } \\
\text { and poly(lactic-co-glycolic } \\
\text { acid) (PLGA) }\end{array}$ & Water & 80 & 32 to 39 & 140 & 1.1 to 7.2 & n.a. & n.a. & [70] \\
\hline $\begin{array}{c}\text { Chitosan } \\
\text { (biopolymer, fat blocker) }\end{array}$ & $\begin{array}{c}\text { Water, } \\
\text { Acetic acid }\end{array}$ & 120 & 55 & 130 & 0.6 to 1.6 & n.a. & n.a. & [83] \\
\hline $\begin{array}{c}\text { PLGA } \\
\text { (biodegradable polymer) }\end{array}$ & $\begin{array}{l}\text { Dichloro- } \\
\text { methane } \\
(\mathrm{DCM})\end{array}$ & 30 to 50 & 20 to 30 & 100 & 2.8 to 4.4 & n.a. & n.a. & [33] \\
\hline $\begin{array}{c}\text { PLGA } \\
\text { suspensions }\end{array}$ & $\mathrm{DCM}$ & 30 to 50 & 20 to 30 & 100 & 0.3 to 1.7 & n.a. & n.a. & [33] \\
\hline $\begin{array}{c}\text { PLGA } \\
\text { (fine carrier supports) }\end{array}$ & DCM & n.a. & n.a. & $\begin{array}{c}100 \\
\left(\mathrm{~N}_{2} / \mathrm{CO}_{2}\right)\end{array}$ & 1 to 16 & n.a. & n.a. & [84] \\
\hline $\begin{array}{l}\text { PLGA and stabilizers } \\
\text { (poloxamer, surfactant) }\end{array}$ & $\begin{array}{l}\text { Acetone, } \\
\text { Ethyl } \\
\text { acetate, } \\
\text { DCM, }\end{array}$ & 50 to 90 & 29 to 36 & $\begin{array}{c}115 \\
\left(\mathrm{~N}_{2} / \mathrm{CO}_{2}\right)\end{array}$ & 2.4 to 8 & $\begin{array}{l}\text { 1'080 to } \\
\text { 1'350 }\end{array}$ & 60 to 85 & {$[44]$} \\
\hline $\begin{array}{l}\text { Hypromellose } \\
\text { (hydroxypropyl- } \\
\text { methylcellulose, for oral } \\
\text { medicaments) }\end{array}$ & Acetone & $36-68$ & n.a. & $\begin{array}{c}90 \text { to } \\
120\end{array}$ & 2 to 10 & 800 & 75 to 91 & {$[50]$} \\
\hline
\end{tabular}


pharmaceuticals on the laboratory-scale has risen sharply after the market launch of the Nano Spray Dryer B-90 in 2009 [19]. The formulations contain drugs and excipients for the treatment of various diseases, including:

- asthma (e.g. salbutamol, terbutaline, or fluticasone) [31,35,51,75-79,89,93-98],

- inflammation (e.g. dexamethasone and azithromycin, or pain and fever reducer indomethacin and nimesulide) [16,31,45,47,48,53,55,64,71,99-101],

- cystic fibrosis (e.g. antibacterial dexketoprofen in Kollidon and Eudragit nanoparticles, or azithromycin in leucine) $[64,70,71]$,

- diabetes (e.g. sitagliptin, vildagliptin, and metformin in mucoadhesive Carbopol and gelatin) [102-104],

- pulmonary arterial hypertension (e.g. resveratrol in poly(caprolactone), or sildenafil in PLGA) $[39,86]$,

- tuberculosis (e.g. capreomycin or pyrazinamide in L-leucine, or ethambutol mixed with chitosan carrier particles) [59-61,66,81,82]

- Alzheimer's and Parkinson's diseases (e.g. nanocrystals of calpain inhibitor steroids) [32,88],

- breastcancer (e.g. simvastatin loaded PLGA particles), or lung cancer (e.g. methotrexate, carboplatin in gelatine, or paclitaxel) [90,91,105-108],

- bacterial infections (e.g. amoxicillin, ciprofloxacin, gatifloxacin, clarithromycin, or levofloxacin),

- fungal infections (e.g. antifungal griseofulvin) [27,52],

- ophthalmic disorders (e.g. calpain inhibitor nanocrystals or dirithromycin incorporated in Kollidon) $[31,32,56]$,

- high blood pressure (e.g. nimodipine in PLGA or pure nicergoline nanoparticles) $[41,65]$,

- congestive heart failure [86] and edema (e.g. diuretic furosemide) [10].

The number of applications reviewed in this study underlines the versatility of the nano spray drying technology to develop nanomedicines. As illustrated in Figure 4 the drug-loaded nano spray dried powders are administered through various ways, such as:

- pulmonary (e.g. optimized respirable particles of 1 to $5 \mu \mathrm{m}$ size),

- oral (e.g. poorly water-soluble drugs like diuretic furosemide [10], pain reducing nimesulide [100], blood vessels dilating nicergoline [67], fever reducing indomethacin [99], anti-inflammatory dexamethasone [46], or steroidal hormone mecigestone [109]),

- intravenous (e.g. simvastatin in PLGA as cancer chemotherapeutics, antipsychotic clozapine and risperidone in PLGA, or small interfering RNAs loaded in human serum albumin particles to treat genetic disorders),

- topically as creams to the skin (e.g. anti-inflammatory dexamethasone, antibacterial gentamicin in gelatinpectin, amoxicillin loaded chitosan, antifungal econazole in cyclodextrin, soy isoflavones for skin cancer treatment or as anti-ageing agent), or as nanoparticulate powder (e.g. as a wound dressing during surgery),

- ophthalmic (e.g. anti-inflammatory steroids in eye drop solutions, or dirithromycin to treat ocular bacterial infections),

- intraperitoneal (e.g. encapsulated paclitaxel as cytostatic in anticancer therapy),

- intravesical (e.g. as drug delivery system to treat local bladder diseases), and even

- cerebral (e.g. with nimodipine in PLGA regulating the dilatation of blood vessels).

The nano spray drying process is gentle and contributes to maintaining the stability and activity of heat-sensitive materials, such as peptides, proteins, hormones and amino acids. This has been confirmed for example by nano spray drying bacitracin (polypeptide antibiotic) [82] or insulin-like growth factor I (anabolic peptide) encapsulated in trehalose, silk fibroin and polysorbate [86] (see Table 4).

To sum up, Table 6 lists typical experimental process parameters for nano spray drying that can be used as first guess values for applying identical or similar substances. The main organic solvents used to dissolve poorly water-soluble drugs are ethanol, acetone, and DCM. With highly diluted solutions containing 0.1 to $1 \%$ $(\mathrm{w} / \mathrm{v})$ solids concentrations, finest solid particles down to $100 \mathrm{~nm}$ can be obtained by nano spray drying.

Pure drug particles in the nanosize dimensions and the amorphous state offer higher absorption rates and bioavailability and encourage future developments in this research area. Nanocapsules, with their reduced size and large specific surface area, provide pronounced improvement in controlled drug release and bioavailability. This enables the generation of target drug delivery systems. Under optimized conditions, uniquely high product yields of about 76 to $96 \%$ can be achieved to process small sample amounts of substances in the range of $10 \mathrm{mg}$ to $2.5 \mathrm{~g}$.

Variations in the yield may occur due to particle depositions around the spray cap and the chamber walls, nozzle blockage, or due to losses during the manual collection of the powder with a rubber spatula (Figure 8).

However, the ability to process small sample amounts makes a nano spray dryer very suitable for testing valuable biological materials such as for example 
$\frac{\sqrt{0}}{0}$

$\frac{1}{t}$

4

के

옹

ำ

$\stackrel{\infty}{\stackrel{\infty}{5}}$

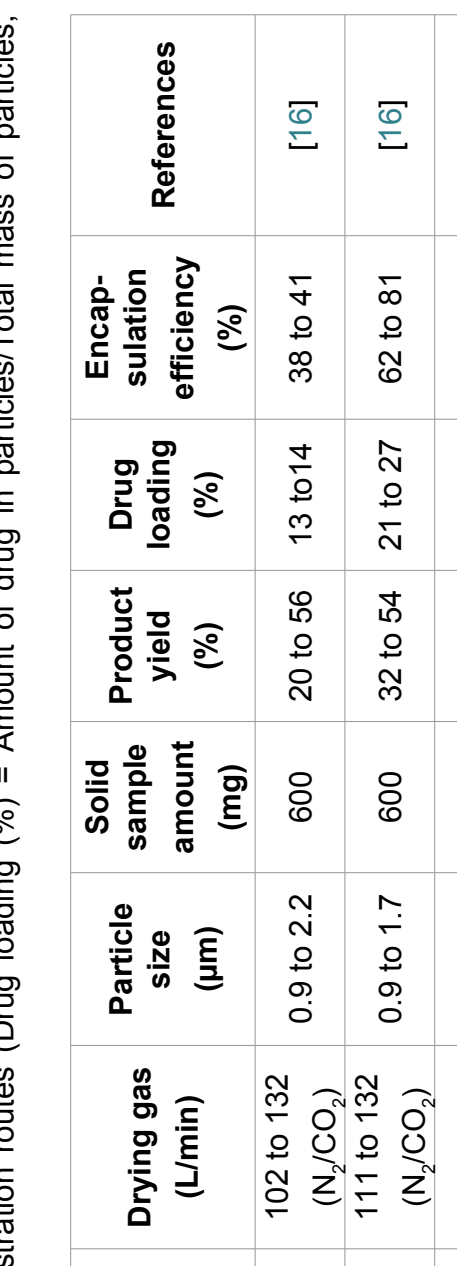

\section{\begin{tabular}{l|l|l}
\hline &
\end{tabular}}

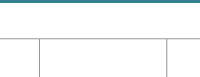

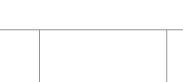

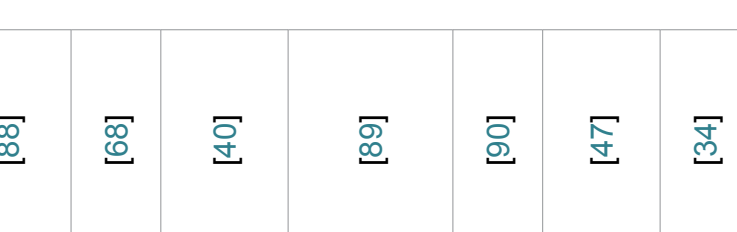

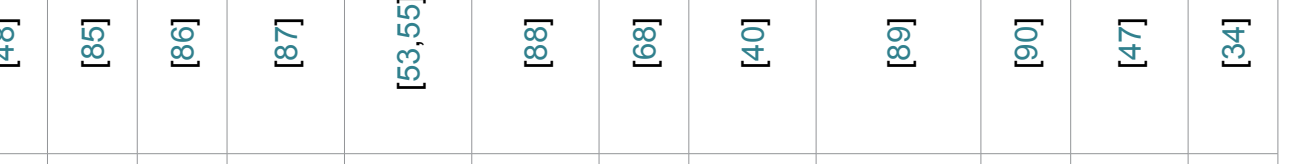

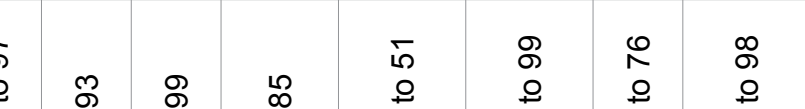

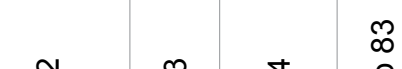

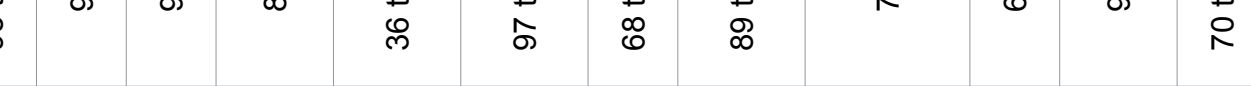




\begin{tabular}{|c|c|c|c|c|}
\hline $\bar{\sigma}$ & ন্ড & $\begin{array}{l}\overline{6} \\
\stackrel{b}{L}\end{array}$ & 离 & 焉 \\
\hline $\begin{array}{l}0 \\
\infty \\
0 \\
\mathbb{2} \\
0\end{array}$ & $\begin{array}{l}\infty \\
\infty \\
0 \\
\infty \\
1\end{array}$ & $\begin{array}{l}\forall \\
\stackrel{+}{0} \\
\stackrel{2}{L}\end{array}$ & $\begin{array}{l}8 \\
\frac{8}{0} \\
0 \\
0\end{array}$ & $\begin{array}{l}\infty \\
0 \\
0 \\
0 \\
0\end{array}$ \\
\hline$\stackrel{\text { Фேं }}{=}$ & 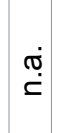 & 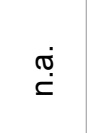 & $\begin{array}{l}0 \\
0 \\
0 \\
0 \\
0\end{array}$ & $\begin{array}{l}\text { 웅 } \\
\stackrel{0}{0} \\
\stackrel{0}{0}\end{array}$ \\
\hline $\begin{array}{l}\infty \\
\infty \\
1 \\
8\end{array}$ & 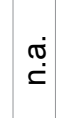 & $\stackrel{\text { Ф் }}{\check{\Sigma}}$ & $\begin{array}{l}\stackrel{L}{N} \\
\stackrel{0}{0} \\
\stackrel{5}{\sim}\end{array}$ & 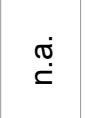 \\
\hline ه্ণ் & 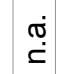 & 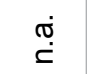 & 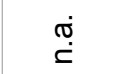 & 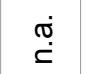 \\
\hline $\begin{array}{l}\stackrel{m}{\leftarrow} \\
\stackrel{0}{0} \\
\stackrel{0}{0}\end{array}$ & $\begin{array}{l}0 \\
0 \\
0 \\
1\end{array}$ & $\begin{array}{l}n \\
0 \\
0 \\
0 \\
m \\
0\end{array}$ & $\begin{array}{l}\stackrel{+}{\vdots} \\
\stackrel{0}{0} \\
\stackrel{0}{0}\end{array}$ & $\begin{array}{l}\hat{0} \\
\dot{m} \\
0 \\
0 \\
0\end{array}$ \\
\hline 음 & 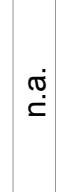 & Фேர் & $\begin{array}{l}\widehat{O^{N}} \\
\bigcup^{N} \\
z^{N} \\
8 \\
\stackrel{0}{0}\end{array}$ & $\stackrel{ }{\sim}$ \\
\hline న & 囟 & $\begin{array}{l}\text { ̊ } \\
\stackrel{9}{0} \\
\stackrel{0}{0}\end{array}$ & $\begin{array}{l}\text { స్ } \\
\stackrel{0}{0} \\
\text { مे }\end{array}$ & 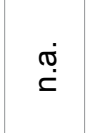 \\
\hline 8 & 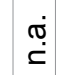 & ৪ & q & $\stackrel{\text { \& }}{q}$ \\
\hline 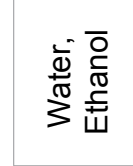 & $\frac{\bar{d}}{\bar{d}}$ & $\begin{array}{l}\overline{0} \\
\frac{1}{0} \\
\frac{ \pm}{ \pm} \\
\sum\end{array}$ & 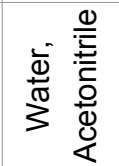 & $\sum_{0}$ \\
\hline 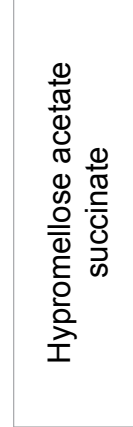 & $\sum_{U}^{U}$ & 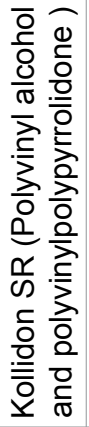 & 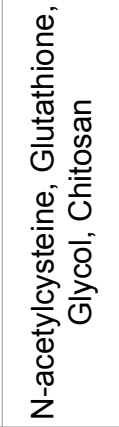 & 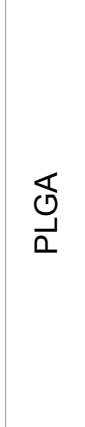 \\
\hline 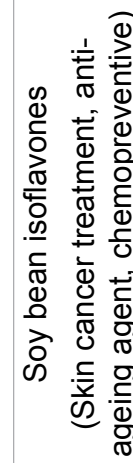 & 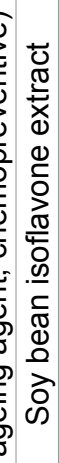 & 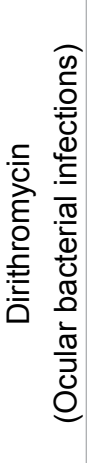 & 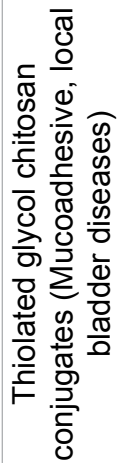 & 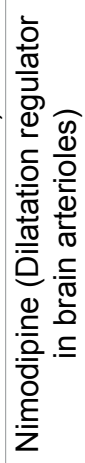 \\
\hline
\end{tabular}

monoclonal antibodies, recombinant proteins, or siRNA-based therapeutics. Moreover, nano spray drying enables the encapsulation of drugs in polymers with high efficiency of over $95 \%$ and adjustable drug loading.

\section{Conclusions}

Nano spray drying has been successfully applied for a wide range of pharmaceutical applications on a laboratory-scale, such as increasing the bioavailability of poorly soluble drugs by nanoisation and structural modification, as well as the encapsulation of nanoparticles, nanoemulsions and nanosuspensions in biocompatible polymeric wall materials for sustained drug release. Encapsulation efficiencies of over $95 \%$ are achieved by adjustable drug loadings. Smallest sample amounts ranging from $10 \mathrm{mg}$ to $2.5 \mathrm{~g}$ with uniquely high yields of over $95 \%$ can be processed, which enables the economical use of valuable active pharmaceutical ingredients.

Compared to conventional spray drying processes, nano spray drying relies on vibrating mesh technology to produce an ultrafine spray. A highly efficient electrostatic powder collector to extend the size spectrum of separable particles to the nanoscale.

The most important adjustable process parameters are the drying gas temperature, the drying gas flow rate, the spray mesh size, the solvent type, the solids concentration in the feed, and the selection of the corresponding excipients, stabilizers and surfactants. Depending on the application, an optimized set of parameters can be found. Submicron spray dried particles can be formed down to a size of only 100 $\mathrm{nm}$ with diluted solutions of 0.1 to $1 \%(\mathrm{w} / \mathrm{v})$ solids concentration. Different particle morphologies can be created, including dense, hollow and porous particles with spherical, wrinkled, or donut shapes.

The drying process is gentle and contributes to maintaining the stability and activity of heat-sensitive materials, such as peptides, proteins, hormones and amino acids. The prepared drug loaded particles are administered in various ways, including pulmonary, oral, intravenous, topically, ophthalmic, intraperitoneal, intravesical, or even cerebral, which underlines the versatility of the nano spray drying technology.

With the introduction of the Nano Spray Dryer B-90 from Büchi Laboretechnik AG (Switzerland) in 2009, the nano spray drying of protein nanotherapeutics became reality on a laboratory-scale [14]. It is expected that the increased customer demand for the laboratory product, combined with promising new applications, will promote and stimulate the development of more industry-relevant models [13]. In order to further explore the potential of nano spray drying, future research should focus on further commercialization of this technology on a pilot and industrial scale. The demand for larger quantities of powder and for the scale-up of nano spray 


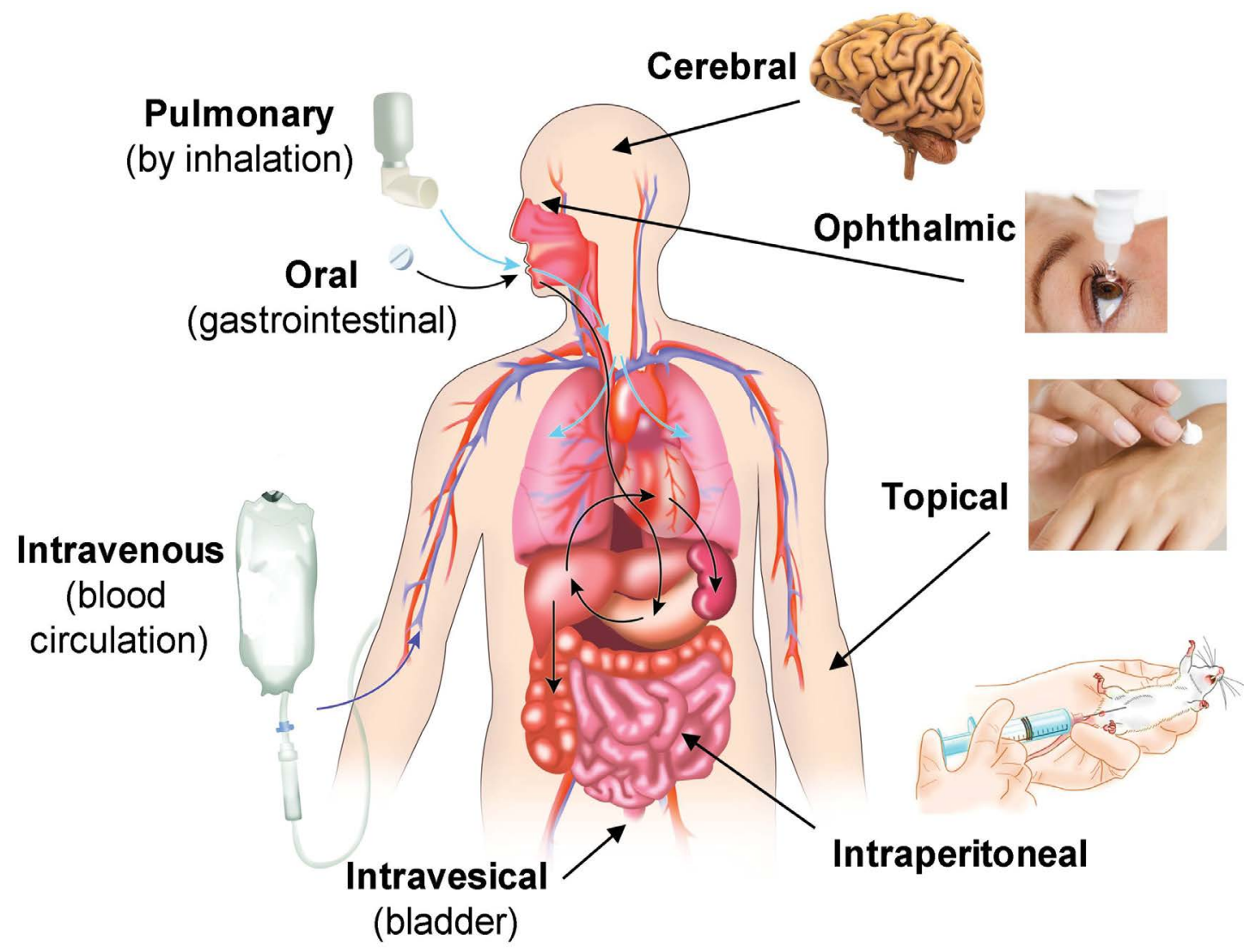

Figure 8: Examples of administration routes of nano spray dried pharmaceuticlas [28].

drying technology is increasing. To achieve this, however, equipment designed for a larger scale is required. A possible scale-up solution for droplet formation and throughput increase are several vibrating mesh atomizers in parallel arrangement (e.g. like ultrasonic humidifiers) or a larger nozzle unit. Industrial-scale electrostatic particle collectors with mechanical rapping devices can be installed for the collection of nanoparticles with an automatic cleaning system to continuously remove the separated particles from the collecting.

The main application trends in nano spray drying are seen in the areas of pulmonary drug delivery, nanotherapeutics, the encapsulation of nanoemulsions with poorly water-soluble active ingredients and the formulation of nanocrystals for a higher bioavailability.

\section{References}

1. Broadhead J, Edmond Rouan SK, Rhodes CT (1992) The spray drying of pharmaceuticals. Drug Dev Ind Pharm 18: 1169-1206.

2. Kawabata $\mathrm{Y}$, Wada K, Nakatani M, Yamada S, Onoue S (2011) Formulation design for poorly water-soluble drugs based on biopharmaceutics classification system: Basic approaches and practical applications. Int J Pharm 420: 1-10.

3. Huang Y, Dai WG (2014) Fundamental aspects of solid dispersion technology for poorly soluble drugs. Acta Pharm Sin B 4: 18-25.

4. Brough C, Williams RO 3rd (2013) Amorphous solid dispersions and nano-crystal technologies for poorly watersoluble drug delivery. Int J Pharm 453: 157-166.
5. Lam J, Vaughan S, Parkins MD (2013) Parkins, Tobramycin Inhalation Powder (TIP): An Efficient Treatment Strategy for the Management of Chronic Pseudomonas Aeruginosa Infection in Cystic Fibrosis. Clin Med Insights Circ Respir Pulm Med 7: 61-77.

6. Konstan MW, Geller DE, Minić P, Brockhaus F, Zhang J, et al. (2011) Tobramycin inhalation powder for P. aeruginosa infection in cystic fibrosis: The EVOLVE trial. Pediatr Pulmonol 46: 230-238.

7. Anderson SD, Daviskas E, Brannan JD, Chan HK (2018) Repurposing excipients as active inhalation agents: The mannitol story. Adv Drug Deliv Rev 133: 45-56.

8. Guntur VP, Dhand R (2007) Inhaled Insulin: Extending the Horizons of Inhalation therapy. Respir Care 52: 911-922.

9. Vehring $R$ (2008) Pharmaceutical particle engineering via spray drying. Pharm Res 25: 999-1022.

10. Li X, Anton N, Arpagaus C, Belleteix F, Vandamme TF (2010) Nanoparticles by spray drying using innovative new technology: The Büchi Nano Spray Dryer B-90. J Control Release 147: 304-310.

11. Schmid C, Arpagaus, Friess W (2009) Evaluation of a Vibrating Mesh Spray Dryer for Preparation of Submicron Particles. Respir Drug Deliv 323-326.

12. Schmid K, Arpagaus C, Friess W (2011) Evaluation of the Nano Spray Dryer B-90 for pharmaceutical applications. Pharm Dev Technol 16: 287-294.

13. Heng D, Lee SH, Ng WK, Tan RB (2011) The Nano Spray Dryer B-90 Expert Opin Drug Deliv 8: 965-972.

14. Lee SH, Heng D, Ng WK, Chan HK, Tan RB (2011) Nano spray drying: A novel method for preparing protein nanoparticles for protein therapy. Int J Pharm 403: 192-200. 
15. Bürki K, Jeon I, Arpagaus C, Betz G (2011) New insights into respirable protein powder preparation using a nano spray dryer. Int J Pharm 408: 248-256.

16. Schafroth N, Arpagaus C, Jadhav UY, Makne S, Douroumis D (2012) Nano and microparticle engineering of water insoluble drugs using a novel spray-drying process. Colloids Surfaces B Biointerfaces 90: 8-15.

17. Arpagaus C, Collenberg A, Rütti D, Assadpour E, Jafari SM (2018) Nano spray drying for encapsulation of pharmaceuticals Int J Pharm 546: 194-214.

18. Arpagaus C, Bless F, Uhlmann M, Schiffmann J, Bertsch SS (2018) High temperature heat pumps: Market overview, state of the art, research status, refrigerants, and application potentials. Energy 152: 985-1010.

19. Arpagaus C, John P, Collenberg A, Rütti D (2017) Chapter 10: Nanocapsules formation by nano spray drying. In: Jafari SM, Nanoencapsulation technologies for the food and nutraceutical industries. Elsevier Inc., 346-401.

20. Arpagaus C (2012) A Novel Laboratory-Scale Spray Dryer to Produce Nanoparticles. Dry Technol 30: 1113-1121.

21. Arpagaus C (2011) Nano Spray Dryer B-90: Literature review and applications.

22. Arpagaus C, Rütti D, Meuri M (2013) Chapter 18: Enhanced Solubility of Poorly Soluble Drugs Via Spray Drying. In: Douroumis D, Fahr A, Drug Delivery Strategies for Poorly Water-Soluble Drugs. John Wiley \& Sons, Ltd., 551-585.

23. Wong TW, John P (2015) Advances in Spray Drying Technology for Nanoparticle Formation. In: May M, Aliofkhazraei, Handbook of Nanoparticles, no. Springer International Publishing, 1-16.

24. Arpagaus C (2010) Spray Drying R\&D Solutions - BÜCHI's Nano Spray Dryer: A world novelty in laboratory scale. ONdrugDelivery 40-41.

25. Wui WT (2015) Nanospray Drying Technology: Existing Limitations and Future Challenges. Recent Pat Drug Deliv Formul 9: 185-186.

26. Kaialy W, Al Shafiee M (2016) Recent advances in the engineering of nanosized active pharmaceutical ingredients: Promises and challenges. Adv Colloid Interface Sci 228: 71-91.

27. Schmid K (2011) Spray drying of protein precipitates and Evaluation of the Nano Spray Dryer B-90. PhD Thesis, Ludwig-Maximilians-University, Munich.

28. Arpagaus C (2018) Nano Spray Drying of Pharmaceuticals," in IDS'2018 - 21st International Drying Symposium, Valencia, Spain, 1-8.

29. Feng AL, Boraey MA, Gwin MA, Finlay PR, Kuehl PJ, et al. (2011) Mechanistic models facilitate efficient development of leucine containing microparticles for pulmonary drug delivery. Int J Pharm 409: 156-163.

30. Sun Y, Song X, Wang J, Yu J (2011) Preparation of lithium carbonate hollow spheres by spray pyrolysis. Cryst Res Technol 46: 173-177.

31. Baba K, Nishida K (2013) Steroid Nanocrystals Prepared Using the Nano Spray Dryer B-90. Pharmaceutics 5: 107114.

32. Baba K, Nishida K (2012) Calpain inhibitor nanocrystals prepared using Nano Spray Dryer B-90. Nanoscale Res Lett 7: 1-9.

33. Beck-Broichsitter M, Schweiger C, Schmehl T, Gessler T, Seeger W, et al. (2012) Characterization of novel spraydried polymeric particles for controlled pulmonary drug delivery. J Control Release 158: 329-335.

34. De Cicco F, Porta A, Sansone F, Aquino RP, Del Gaudio $P$ (2014) Nanospray technology for an in situ gelling nanoparticulate powder as a wound dressing. Int J Pharm 473: 30-37.

35. Littringer Em, Zellnitz S, Hammernik K, Adamer V, Friedl H, et al. (2013) Spray Drying of Aqueous Salbutamol Sulfate Solutions Using the Nano Spray Dryer B-90 - The Impact of Process Parameters on Particle Size. Dry Technol 31: 1346-1353.

36. Kim LT, NganSan-Lang Wang, Minh Hiep D, Luong PM, Vui NT, et al. (2014) Preparation of chitosan nanoparticles by spray drying, and their antibacterial activity. Res Chem Intermed 40: 2165-2175.

37. Pérez-Masiá R, López-Nicolás R, Periago MJ, Ros G, Lagaron JM, et al. (2015) Encapsulation of folic acid in food hydrocolloids through nanospray drying and electrospraying for nutraceutical applications. Food Chem 168: 124-133.

38. Nandiyanto ABD, Okuyama K (2011) Progress in developing spray-drying methods for the production of controlled morphology particles: From the nanometer to submicrometer size ranges. Adv Powder Technol 22: 1-19.

39. Beck-Broichsitter M, Paulus IE, Greiner A, Kissel T (2015) Modified vibrating-mesh nozzles for advanced spray-drying applications. Eur J Pharm Biopharm 92: 96-101.

40. Panda A, Meena J, Katara R, Majumdar DK (2014) Formulation and characterization of clozapine and risperidone co-entrapped spray-dried PLGA nanoparticles. Pharm Dev Technol 21: 43-53.

41. Bege N, Renette T, Endres T, Beck-Broichsitter M, Hänggi D, et al. (2013) In situ forming nimodipine depot system based on microparticles for the treatment of posthemorrhagic cerebral vasospasm. Eur J Pharm Biopharm 84: 99-105.

42. Dahili LA, Kelemen-Horváth I, Feczkó T (2015) 2,4-Dichlorophenol removal by purified horseradish peroxidase enzyme and crude extract from horseradish immobilized to nano spray dried ethyl cellulose particles. Process Biochem 50: 1835-1842.

43. Dahili LA, Feczkó T (2015) Cross-linking of Horseradish Peroxidase Enzyme to Fine Particles Generated by Nano Spray Dryer B-90. Period Polytech Chem Eng 59: 209-214.

44. Draheim C, de Crécy F, Hansen S, Collnot EM, Lehr CM (2015) A Design of Experiment Study of Nanoprecipitation and Nano Spray Drying as Processes to Prepare PLGA Nano- and Microparticles with Defined Sizes and Size Distributions. Pharm Res 32: 2609-2624.

45. Durli TL, Dimer FA, Fontana MC, Pohlmann AR, Beck RC, et al. (2014) Innovative approach to produce submicron drug particles by vibrational atomization spray drying: influence of the type of solvent and surfactant. Drug Dev Ind Pharm 40: 1011-1020.

46. Perecin CJ (2015) Magnetite Nanoparticles Encapsulated with PCL and Poloxamer by Nano Spray Drying technique," in XIV Brazil MRS (Materials Research Society) Meeting, Rio.

47. Beber TC, Andrade DF, Kann B, Fontana MC, Coradini K, et al. (2014) Submicron polymeric particles prepared by vibrational spray-drying: Semisolid formulation and skin penetration/permeation studies. Eur J Pharm Biopharm 88: 602-613.

48. Fontana MC, Durli TL, Pohlmann AR, Guterres SS, Beck RCR (2014) Polymeric controlled release inhalable powder produced by vibrational spray-drying: One-step preparation and in vitro lung deposition. Powder Technol 258: 49-59. 
49. Beck-Broichsitter M, Strehlow B, Kissel T (2015) Direct fractionation of spray-dried polymeric microparticles by inertial impaction. Powder Technol 286: 311-317.

50. Gu B, Linehan B, Tseng YC (2015) Optimization of the Büchi B-90 spray drying process using central composite design for preparation of solid dispersions. Int J Pharm 491: 208-217.

51. Zellnitz S, Narygina O, Resch C, Schroettner H, Urbanetz NA (2015) Crystallization speed of salbutamol as a function of relative humidity and temperature. Int J Pharm 489: 170176.

52. Maged A, Mahmoud AA, Ghorab MM (2017) HydroxypropylBeta-Cyclodextrin as Cryoprotectant in Nanoparticles Prepared by Nano-Spray Drying Technique. J Pharm Sci Emerg Drugs 5: 1-5.

53. Öztürk, Yenilmez E, Yazan Y (2015) Preparation and Characterization of Dexketoprofen Tromethamol Loaded Kollidon-SR Nanoparticles," in ISOPS 11th International Symposium on Pharmaceutical Sciences,Ankara, Turkey,

54. Suryaprakash RC, Lohmann FP, Wagner M, Abel M, Varga A (2014) Spray drying as a novel and scalable fabrication method for nanostructured $\mathrm{CsH} 2 \mathrm{PO} 4$, Pt-thinfilm composite electrodes for solid acid fuel cells. RSC Adv 4: 60429-60436.

55. Öztürk, Yenilmez E, Arslan R, Şenel B, Yazan Y (2017) Dexketoprofen Trometamol-Loaded Kollidon ${ }^{\circledR}$ SR and Eudragit $\circledast$ RS 100 Polymeric Nanoparticles: Formulation and In Vitro-In Vivo Evaluation. Lat Am J Pharm Am J Pharm 36: 2153-2165.

56. Basran E (2017) Ocular Application of Dirithromycin Incorporated Polymeric Nanoparticles: an In Vitro Evaluation. Turkish J Pharm Sci 14: 191-200.

57. Amsalem O, Nassar T, Benhamron S, Lazarovici P, Benita S, et al. (2017) Solid nano-in-nanoparticles for potential delivery of siRNA. J Control Release 257: 144-155.

58. Denora N, Lopedota A, Perrone M, Laquintana V, lacobazzi RM, et al. (2016) Spray-dried mucoadhesives for intravesical drug delivery using $\mathrm{N}$-acetylcysteine- and glutathione-glycol chitosan conjugates. Acta Biomater 43: 170-184.

59. Kaewjan K, Srichana T (2016) Nano spray-dried pyrazinamide-L-leucine dry powders, physical properties and feasibility used as dry powder aerosols. Pharm Dev Technol 21: 68-75.

60. Schoubben A, Blasi P, Giontella A, Giovagnoli S, Ricci M (2015) Powder, capsule and device: An imperative ménage à trois for respirable dry powders. Int J Pharm 494: 40-48.

61. Schoubben A, Blasi P, Marenzoni ML, Barberini L, Giovagnoli S, et al. (2013) Capreomycin supergenerics for pulmonary tuberculosis treatment: Preparation, in vitro, and in vivo characterization. Eur J Pharm Biopharm 83: 388395.

62. Dimer F, de Souza Carvalho-Wodarz C, Haupenthal J, Hartmann R, Lehr CM (2015) Lehr, Inhalable Clarithromycin Microparticles for Treatment of Respiratory Infections. Pharm Res 32: 3850-3861.

63. Son YJ, Longest PW, Tian G, Hindle M (2013) Evaluation and modification of commercial dry powder inhalers for the aerosolization of a submicrometer excipient enhanced growth (EEG) formulation. Eur J Pharm Sci 49: 390-399.

64. Aquino RP, Stigliani M, Del Gaudio P, Mencherini T, Sansone F, et al. (2014) Nanospray Drying as a Novel Technique for the Manufacturing of Inhalable NSAID Powders. The Scientific World Journal.
65. Martena V, Censi R, Hoti E, Malaj L, Martino PD (2012) A new nanospray drying method for the preparation of nicergoline pure nanoparticles. J Nanoparticle Res 14: $1-10$.

66. Ahmad MI, Ungphaiboon S, Srichana T (2014) The development of dimple-shaped chitosan carrier for ethambutol dihydrochloride dry powder inhaler. Drug Dev Ind Pharm 41: 791-800.

67. Blasi P, Schoubben A, Giovagnoli S, Rossi C, Ricci M (2010) Alginate micro- and nanoparticle production by spray drying. Proc Meet Lact as a Carr Inhal Prod Parma, Italy, 137-138.

68. Cerchiara T, Abruzzo A, di Cagno M, Bigucci F, BauerBrandl A, et al. (2015) Chitosan based micro- and nanoparticles for colon-targeted delivery of vancomycin prepared by alternative processing methods. Eur J Pharm Biopharm 92: 112-119.

69. Jain (2014) Crosslinking albumin for drug release from spray dried particles, Master Thesis, Electronic Thesis and Dissertations, Paper 674," University of Louisville, USA, 2014.

70. Torge A, Grützmacher P, Mücklich F, Schneider M (2017) The influence of mannitol on morphology and disintegration of spray-dried nano-embedded microparticles. Eur J Pharm Sci 104: 171-179.

71. Hindle M, Kaviratna A, Yamarthi D, Longest PW (2015) Characterization of Spray Dried Azithromycin Dry Powders for Inhalation. Journal of Aerosol Medicine and Pulmonary Drug Delivery 28: A9-A9.

72. Nguyen TV, Nguyen TTH, Wang SL, Vo TPK, Nguyen AD (2017) Preparation of chitosan nanoparticles by TPP ionic gelation combined with spray drying, and the antibacterial activity of chitosan nanoparticles and a chitosan nanoparticle-amoxicillin complex. Res Chem Intermed 43: 3527-3537.

73. Merchant Z, Taylor KM, Stapleton P, Razak SA, Kunda N, et al. (2014) Engineering hydrophobically modified chitosan for enhancing the dispersion of respirable microparticles of levofloxacin. Eur J Pharm Biopharm 88: 816-829.

74. Rampino $A$, Borgogna $M$, Blasi $P$, Bellich $B$, Cesàro $A$ (2013) Chitosan nanoparticles: Preparation, size evolution and stability. Int J Pharm 455: 219-228.

75. Yang X, Xu Y, Cai Y, Li H (2015) Novel nano-spray-dried powders for efficient pulmonary drug delivery. J Control Release 213: e117-e118.

76. Son YJ, Worth Longest P, Hindle M (2013) Aerosolization Characteristics of Dry Powder Inhaler Formulations for the Excipient Enhanced Growth (EEG) Application: Effect of Spray Drying Process Conditions on Aerosol Performance. Int J Pharm 443: 137-145.

77. Behara SR, Longest PW, Farkas DR, Hindle M (2014) Development and Comparison of New High-Efficiency Dry Powder Inhalers for Carrier-Free Formulations. J Pharm Sci 103: 465-477.

78. Behara SR, Farkas DR, Hindle M, Longest PW (2014) Development of a High Efficiency Dry Powder Inhaler: Effects of Capsule Chamber Design and Inhaler Surface Modifications. Pharm Res 31: 360-372.

79. Behara SR, Longest PW, Farkas DR, Hindle M (2014) Development of high efficiency ventilation bag actuated dry powder inhalers. Int J Pharm 465: 52-62.

80. Guo J, LiH (2013) Nano spray drying of alkaline phosphatase with $\beta$-cyclodextrin and I-leucine for inhalation. J Control Release 172: e107. 
81. Schoubben A, Giovagnoli S, Tiralti MC, Blasi P, Ricci M (2014) Capreomycin inhalable powders prepared with an innovative spray-drying technique. Int J Pharm 469: 132139.

82. Schoubben, Giovagnoli S, Blasi P, Ricci M (2013) Production of a capreomycin sulfate inhalable powder by nano spray-drying.

83. Gautier S, Arpagaus C, Schafroth N, Meuri M, Deschamps A et al. (2010) Very fine chitosan microparticles with narrow \& controlled size distribution using spray-drying technologies". Drug Deliv Technol 10: 30-37.

84. Dahili LA, Nagy E, Feczkó T (2017) 2,4-Dichlorophenol Enzymatic Removal and Its Kinetic Study Using Horseradish Peroxidase Crosslinked to Nano Spray-Dried Poly(LacticCo-Glycolic Acid) Fine Particles. J Microbiol Biotechnol 27: 768-774.

85. Schultz I, Vollmers F, Lühmann T, Rybak JC, Wittmann R, et al. (2015) Pulmonary Insulin-like Growth Factor I Delivery from Trehalose and Silk-Fibroin Microparticles. ACS Biomater Sci Eng 1: 119-129.

86. Dimer FA, Ortiz M, Pohlmann AR, Guterres SS (2015) Inhalable resveratrol microparticles produced by vibrational atomization spray drying for treating pulmonary arterial hypertension. J Drug Deliv Sci Technol 29: 152-158.

87. Sithole MN, Choonara YE, du Toit LC, Kumar P, Marimuthu $\mathrm{T}$, et al. (2017) Development of a Novel Polymeric Nanocomposite Complex for Drugs with Low Bioavailability. AAPS PharmSciTech 6: 1-12.

88. E Al-Dhubiab (2013) Formulation and In Vitro Evaluation of Gelatin Nanospheres for the Oral Delivery of Selegiline. Curr Nanosci 9: 21-25.

89. Harsha S, Al-dhubiab BE, Nair AB, Attimarad M, Venugopala $\mathrm{KN}$, et al. (2017) Pharmacokinetics and tissue distribution of microspheres prepared by spray drying technique: Targeted drug delivery. Biomed Res 28: 3387-3396.

90. Anzar N, Mirza MA, Anwer K, Khuroo T, Alshetaili AS, et al. (2018) Preparation, evaluation and pharmacokinetic studies of spray dried PLGA polymeric submicron particles of simvastatin for the effective treatment of breast cancer. J Mol Liq 249: 609-616.

91. Del Gaudio P, Russo P, Rodriguez Dorado R, Sansone F, Mencherini T, et al. (2017) "Submicrometric hypromellose acetate succinate particles as carrier for soy isoflavones extract with improved skin penetration performance. Carbohydr Polym 165: 22-29.

92. Del Gaudio P, Sansone F, Mencherini T, De Cicco F, Russo P, et al. (2016) Nanospray Drying as a Novel Tool to Improve Technological Properties of Soy Isoflavone Extracts. Planta Med 83: 426-433.

93. Zellnitz S, Schroettner H, Urbanetz NA (2014) Surface modified glass beads as model carriers in dry powder inhalers-influence of drug load on the fine particle fraction. Powder Technol 268: 377-386.

94. Zellnitz S, Schroettner H, Urbanetz NA (2015) Influence of surface characteristics of modified glass beads as model carriers in dry powder inhalers (DPIs) on the aerosolization performance. Drug Dev Ind Pharm 41: 1710-1717.

95. Arpagaus C, Schafroth N, Meuri M (2010) Laboratory Scale Spray Drying of Lactose: A Review, best@buchi Information Bulletin, Number 57/2010.

96. Pinto JT, Radivojev S, Zellnitz S, Roblegg E, Paudel A (2017) How does secondary processing affect the physicochemical properties of inhalable salbutamol sulphate particles? A temporal investigation. Int J Pharm
528: 416-428.

97. Faulhammer E, Zellnitz S, Wutscher T, Stranzinger S, Zimmer A (2018) Performanc indicators for carrier based DPIs: Carrier surface properties for capsule filling and API properties for in vitro aerosolization. Int J Pharm 536: 326335.

98. Faulhammer E, Wahl V, Zellnitz S, Khinast JG, Paudel A (2015) Carrier-based dry powder inhalation: Impact of carrier modification on capsule filling processability and in vitro aerodynamic performance. Int J Pharm 491: 231-242.

99. Martena V, Censi R, Hoti E, Malaj L, Di Martino P (2012) Indomethacin nanocrystals prepared by different laboratory scale methods: Effect on crystalline form and dissolution behavior. J Nanoparticle Res 14: 12.

100. Rascioni R, Censi R, Malaj L, Di Martino P (2016) Effect of particle size reduction and crystalline form on dissolution behaviour of nimesulide. J Therm Anal Calorim 123: 2213-2223.

101. Lee SH, Teo J, Heng D, Ng WK, Chan HK, et al. (2013) Tan Synergistic combination dry powders for inhaled antimicrobial therapy: Formulation, characterization and in vitro evaluation. Eur J Pharm Biopharm 83: 275-284.

102. Harsha SN, Aldhubiab BE, Nair AB, Alhaider IA, Attimarad $M$, et al. (2015) Nanoparticle formulation by Büchi B-90 Nano Spray Dryer for oral mucoadhesion. Drug Des Devel Ther 9: 273-282.

103. Sree Harsha N, Bander E Aldhubiab, Ibrahim Abdulrahman Alhaider, Mahesh Attimarad, Anroop Nair (2013) Carbopol 934-P loaded with vildagliptin for diabetic delivery: In Vitro and In Vivo Evaluation of Nanoparticles. Curr Nanosience 9: 642-647.

104. Harsha N (2015) "In Vitro and In Vivo Evaluation of Nanoparticles Prepared by Nano Spray Drying for Stomach Mucoadhesive Drug Delivery. Dry Technol 33: 1199-1209.

105. Harsha S, Al-Dhubiab BE, Nair AB, Al-Khars M, Al-Hassan $M$, et al. (2015) Novel Drying Technology of Microsphere and Its Evaluation for Targeted Drug Delivery for Lungs. Dry Technol 33: 502-512.

106. Harsha S, Al-Khars M, Al-Hassan M, Kumar NP, Nair AB, et al. (2014) Pharmacokinetics and tissue distribution of spray-dried carboplatin microspheres: Lung targeting via intravenous route. Arch Pharm Res 37: 352-360.

107. Zernov AL, Bonartsev Ap, Yakovlev SG, Myshkina VL, Makhina TK, et al. (2017) Low molecular weight poly(3-hydroxybutyrate) microparticles synthesized by piezoelectric spray drying for the sustained release of paclitaxel. Nanotechnologies Russ 12: 218-225.

108. Bonartsev AP, Zernov AL, Yakovlev SG, Zharkova II, Myshkina VL, et al. (2017) New Poly(3-hydroxybutyrate) Microparticles with Paclitaxel Sustained Release for Intraperitoneal Administration. Anticancer Agents Med Chem 17: 434-441.

109. Nazarov A, Zavarzin I, Nazarov G, Aksenov A, Levina I (2013) Preparation and Bioavailability Evaluation of Micronized Steroidal Mecigestone Drug Substance. Pharm Chem J 49: 706-710. 